TITLE:

\title{
Chromosome number of a bivalve- inhabiting hydroid, Eugymnanthea japonica (Leptomedusae : Eirenidae) from Japan
}

\author{
$\operatorname{AUTHOR}(\mathrm{S})$ :
}

Kubota, Shin

\section{CITATION:}

Kubota, Shin. Chromosome number of a bivalve-inhabiting hydroid, Eugymnanthea japonica (Leptomedusae: Eirenidae) from Japan. PUBLICATIONS OF THE SETO MARINE BIOLOGICAL LABORATORY 1992, 35(6): 383-386

ISSUE DATE:

1992-11-30

URL:

http://hdl.handle.net/2433/176208

RIGHT: 


\title{
Chromosome number of a bivalve-inhabiting hydroid, Eugymnanthea japonica (Leptomedusae: Eirenidae) from Japan
}

\author{
Shin Kubota \\ Seto Marine Biological Laboratory, Kyoto University, Shirahama, \\ Wakayama 649-22, Japan
}

With Text-figures 1-5 and Table 1

\begin{abstract}
The chromosome number of a bivalve-inhabiting hydroid, Eugymnanthea japonica, was determined to be $n=15$ and $2 n=30$ by an air-drying method, using six populations commensal with Mytilus edulis galloprovincialis and Crassostrea gigas in central and southern Japan. No geographical variation of chromosome number of this species was found.
\end{abstract}

In Japan a commensal hydroid, Eugymnanthea japonica Kubota, 1979, is distributed southwards from the Izu Peninsula, associated mainly with Crassostrea gigas (Thunberg) and Mytilus edulis galloprovincialis Lamarck (Kubota 1991a, c, 1992b, c). This hydroid's medusa is variable in the number and position of the statocysts and marginal warts, at least 44 combinations of these characters being recognized (Kubota 1985a, 1991c). Furthermore, two putative diagnostic characters of the medusa are not always stable (Kubota 1991c), and in rare instances the medusa is similar to that of Eugymnanthea inquilina Palombi, 1935 (Kubota 1989). On the other hand, Eugymnanthea japonica does not freely cross with the related spceies Eutima japonica Uchida, 1925 (Kubota 1991a, see also Kubota 1992a). As one of a series of studies on the systematics of bivalve-inhabiting hydroids, the present paper reports a chromosome analysis of Eugymnanthea japonica.

\section{Material and Methods}

Six populations of Eugymnanthea japonica commensal with the bivalves Mytilus edulis galloprovincialis and Crassostrea gigas in the central and southern parts of Japan (Table 1) were examined. Hosts were collected in the intertidal zone between December 1985 and August 1988. The precise localities and the methods of culturing the hydroids in the laboratory were described by Kubota (1991a, c, 1992c). The chromosomal preparations were made from whole medusa buds, using the air-drying method. Hydroids with well-developed medusa buds were maintained in a $0.001-0.01 \%$ colchicine solution in filtered seawater for up to 1.5 days. Then the specimens were exposed to $1 \%$ sodium citrate for 10-20 minutes, and fixed in Carnoy's solution for at least a few hours. The fixed specimens were macerated in a mixture of lactic acid ( 1 volume), glacial acetic acid ( 3 volume), and distilled water ( 1 volume). When the specimens became transparent in this solution, they were tranferred onto a slide glass and torn into pieces with a pair of needles, whereupon drops of Carnoy's solution were applied by a Pasteur capillary pipet to spread the cells. After the preparations were dried at room temperature they were stained by $2 \%$ Giemsa solution with a phosphate buffer $\left(\mathrm{KH}_{2} \mathrm{PO}_{4}+\mathrm{Na}_{2} \mathrm{HPO}_{4}\right.$,

Publ. Seto Mar. Biol. Lab., 35(6), 383-386, $1992 . \quad$ (Article 18) 
$\mathrm{pH}=7.0$ ) and rinsed with tap water. No cover slips were employed. The chromosomes were observed using a $100 \mathrm{x}$ no cover objective and figured using a drawing tube attached to the microscope.

\section{Results and Discussion}

The chromosomes of Eugymnanthea japonica were small, under $3 \mu \mathrm{m}$ in both length and width (Figs. 1-5), and only the chromosome number could be analysed. The haploid and diploid chromosome numbers were $n=15$ and $2 n=30$, respectively (Table 1). No geographical variation of chromosome number was found.

The chromosome number of Eugymnanthea japonica may be identical with that of the related species Eutima japonica (see Kubota 1985b, 1992a). Furthermore, in the family Eirenidae to which these two bivalve-inhabiting hydroids belong, Werner (1968b) reported $2 \mathrm{n}=30$ in Eutonina indicans Romanes, which has a free-living hydroid stage. Werner (1968a) also found the chromosome number of Eucheilota maculata Hartlaub as $2 n=30$. This last-mentioned species also has a free-living hydroid stage and belongs to the family Eucheilotidae, which is one of the most closely related hydroid families to the Eirenidae (Bouillon 1985). However, according to

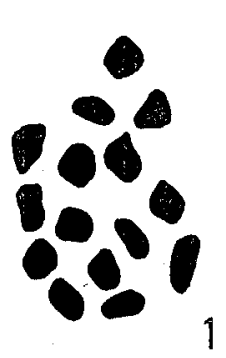

1

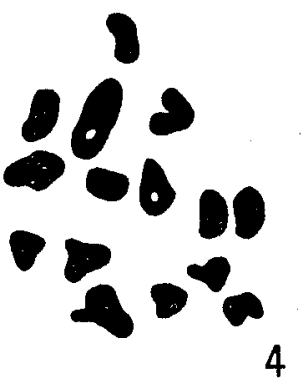

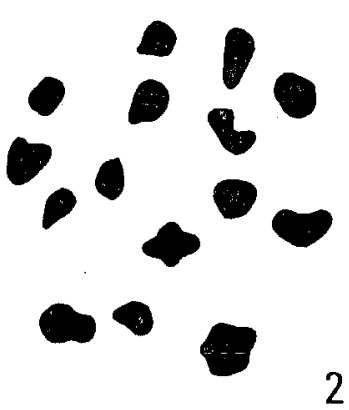

2

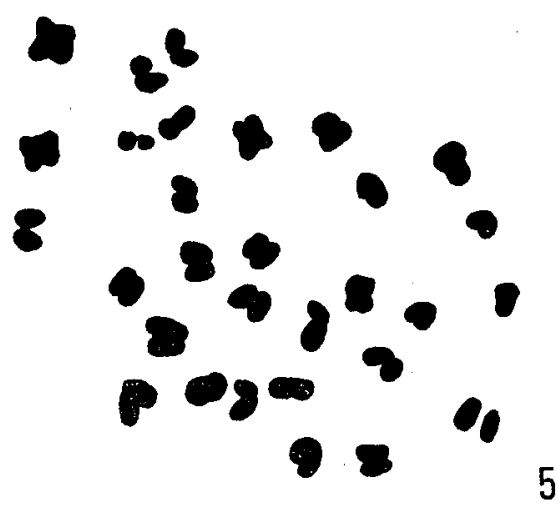

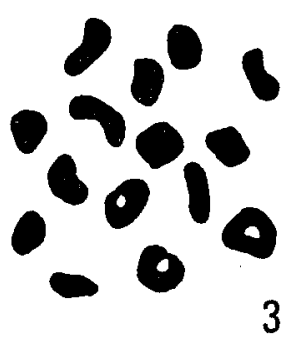

3 
Table 1. The haploid and the diploid chromosome numbers of Eugymnanthea japonica from Japan.

\begin{tabular}{|c|c|c|c|c|c|c|c|c|c|c|c|c|c|}
\hline \multirow{3}{*}{ Locality } & \multirow{3}{*}{$\begin{array}{l}\text { No. of specimens } \\
\text { examined (no. of } \\
\text { hosts used) }\end{array}$} & \multicolumn{12}{|c|}{$\begin{array}{l}\text { No. of cells containing the following numbers of } \\
\text { chromosomes*: }\end{array}$} \\
\hline & & \multirow{2}{*}{$\begin{array}{l}\mathrm{n}= \\
12\end{array}$} & \multirow{2}{*}{$=13$} & \multirow[b]{2}{*}{14} & \multirow[b]{2}{*}{15} & \multirow[b]{2}{*}{16} & \multirow[b]{2}{*}{18} & \multicolumn{2}{|c|}{$2 n=$} & \multirow[b]{2}{*}{29} & \multirow[b]{2}{*}{30} & \multirow[b]{2}{*}{31} & \multirow[b]{2}{*}{32} \\
\hline & & & & & & & & 27 & 28 & & & & \\
\hline Atami & $6(1)$ & & & & 26 & & & & & 1 & 12 & & \\
\hline Shimizu & $2(1)+12(2)$ & & & 7 & 15 & & & & & 1 & 6 & & \\
\hline Shirahama & $3(2)+5(2)$ & 1 & 3 & 13 & 75 & 9 & 1 & 1 & 1 & 1 & 16 & & \\
\hline Furue & $2(1)$ & & & 3 & 46 & & & & & & & & \\
\hline Kushi & $1(1)$ & & & & & & & & & & 10 & 1 & \\
\hline \multirow[t]{2}{*}{ Takeshiki } & $5(1)$ & & & 1 & 20 & 2 & & & 1 & 5 & 21 & & 1 \\
\hline & $19(7)+17(4)$ & 1 & 3 & 24 & 182 & 11 & 1 & 1 & 2 & 8 & 65 & 1 & 1 \\
\hline
\end{tabular}

*: Cells with an uncertain chromosome number, e.g. $2 n=29 / 30$ or $n=14 / 15$, omitted.

Tardent (1978), the chromosome number of four species of two other different families in the Thecata-Leptomedusae was neither $2 n=30$ nor $n=15(n=6,2 n=12$; $\mathrm{n}=8 ; \mathrm{n}=10,2 \mathrm{n}=20 ; \mathrm{n}=17)$. On the other hand, among the Athecata-Anthomedusae, the identical diploid chromosome number $2 n=30$ was described in the freeliving hydroid Hydrocoryne miurensis Stechow, 1907 in the Hydrocorynidae (Kubota 1988) and in the fish-commensal hydroid Stylactaria piscicola (Komai, 1932) in the Hydractiniidae (Kubota 1991b). Although the chromosomal study of hydrozoans is rather poor, variable chromosome number was reported on $H y d r a$ species, i.e. $\mathrm{n}=$ $6,2 n=12 ; \mathrm{n}=12-14 ; \mathrm{n}=15,2 \mathrm{n}=30 ; \mathrm{n}=16,2 \mathrm{n}=32$ (Tardent 1978, p. 144; Xinbai et al. 1987).

\section{Acknowledgments}

I wish to express my sincere gratitude to Dr. Syuiti Abe, Chromosome Research Unit, Faculty of Science, Hokkaido University, for his kind guidance in making the chromosome preparations. Cordial thanks are due to Dr. Mark J. Grygier for his valuable linguistic suggestions.

\section{References}

Bouillon, J. 1985. Essai de classification des Hydropolypes-Hydroméduses (Hydrozoa-Cnidaria). Indo-Malayan Zool., 1 : 29-243.

Kubota, S. 1985a. Systematic study on a bivalve-inhabiting hydroid Eugymnanthea inquilina japonica Kubota from central Japan. J. Fac. Sci. Hokkaido Univ. Ser. 6, Zool, 24(1): 70-85.

- - 1985b. Systematic study on a bivalve-inhabiting hydroid Eucheilota intermedia Kubota from central Japan. J. Fac. Sci. Hokkaido Univ. Ser. 6, Zool., 24(2): 122-143.

- 1988. Taxonomic study on Hydrocoryne miurensis (Hydrozoa: Hydrocorynidae) in Japan. Publ. Seto Mar. Biol. Lab., 33(1/3): 1-18.

- 1989. Systematic study of a paedomorphic derivative hydrozoan Eugymnanthea (ThecataLeptomedusae). Zool. Sci., 6: 147-154.

- 1991a. Crossing-experiments between Japanese populations of three hydrozoans symbiotic with bivalves. Hydrobiologia, 216/217: 429-436.

- 1991b. Second finding of Stylactaria piscicola (Komai, 1932) comb. nov. (Hydrozoa: Hy- 
dractiniidae) from off Atsumi Peninsula, Japan. Publ. Seto Mar. Biol. Lab., 35(1/3): 11-15.

- 1991c. The stability of diagnostic characters of the medusa of a bivalve-inhabiting hydrozoan Eugymnanthea japonica Kubota in Japan. Proc. Japan. Soc. Syst. Zool., 44: 1-7.

-1992a. Eucheilota intermedia Kubota is a distinct taxon and the third form of Eutima japonica Uchida (Hydrozoa; Leptomedusae). Zool. Sci., 9: 231-235.

- - 1992b. Eugymnanthea japonica Kubota (Hydrozoa, Eirenidae) commensal with a host at a depth of $20 \mathrm{~m}$. Benthos Research, 43: 1-5.

-1992c. Four bivalve-inhabiting hydrozoans in Japan differing in range and host preference. Sci. Mar., 56(2-3) : 149-159.

Tardent, P. 1978. Coelenterata, Cnidaria. In "Morphogenese der Tiere" (Seidel, F., ed.), Lief. 1, A-I : 69-415, Gustav Fischer Verlag, Jena.

Werner, B. 1968a. Polypengeneration und Entwicklungsgeschichte von Eucheilota maculata (ThecataLeptomedusae). Helgoländer wiss. Meeresunters., 18: 136-168.

- 1968b. Polypengeneration und Entwicklung von Eutonina indicans (Thecata-Leptomedusae). Helgoländer wiss. Meeresunters., 18: 384-403.

Xinbai, S., D. Shuwei, F. Xueming, Z. Hongling \& L. Jiaying. 1987. The characteristics of Hydra robusta and its difference from $H$. oligactis. Acta Zool. Sinica. 33(2): 174-179, pl. 1. 